Araştırma Makalesi - Research Article

\title{
Onkolitik Virüs ile Matematiksel Tümör Modeli
}

\author{
Tuğba Akman Y1ldız ${ }^{1 *}$
}

Geliş / Received: 23/07/2019

Revize / Revised: 15/10/2020

Kabul / Accepted: 09/11/2020

ÖZ

Besin, sağlıklı hücreler, tümör hücreleri ve onkolitik virüs arasındaki etkileşim için verilen dört boyutlu matematiksel model [29], bu çalışmada beş boyutlu adi diferansiyel denklem sistemi şeklinde genişletilmiştir. Tümör hücreleri onkolitik virüs ile etkileşime geçtiğinden, enfekte olmuş tümör hücreleri de modele dâhil edilmiştir. Onkolitik virüsün tümörü yok etmedeki rolünü incelemek için, tümörün sistemde olmadığı durumlar için kararlılık analizi yapılmıştır. Tümör ve sağlıklı hücrelerden yoksun bir sistemin kararlılığının, sisteme verilen virüs dozunun minimum değerine bağlı olduğu tespit edilmiştir. Tümörün olmadığı ve sağlıklı hücrelerin var olduğu durumda ise, sistemin kararlılığı için elde edilen minimum virüs dozunun, bir önceki dozdan daha küçük olduğu gözlemlenmiştir. Böylece, sistemde sağlıklı hücrelerin bulunmasının, tümörün yok edilme şansını artırdığı ve gerekli ilaç dozunun azaltılmasını sağladığı sonucuna varılmıştır. Son olarak, elde edilen kararlılık analizi için nümerik sonuçlar elde edilmiş ve sistemin kararlılı̆̆

Anahtar Kelimeler- Tümör Modeli, Kararlılık Analizi, Onkolitik Virüs, Viroterapi

1*Sorumlu yazar iletişim: takman@thk.edu.tr (http://orcid.org/0000-0003-1206-2287)

Department of Industrial Engineering, Faculty of Engineering, University of Turkish Aeronautical Association, 06790, Ankara, Turkey 


\title{
A Mathematical Tumor Model with Oncolytic Virus
}

\begin{abstract}
In this study, a four-dimensional model [29] that is given for interactions between nutrient, healthy cells, tumor cells, and oncolytic virus, is extended with a five-dimensional ordinary differential equations system. Infected tumor cells are included in the model since oncolytic virus infects tumor cells. In order to investigate the role of oncolytic virus in eradication of tumor burden, stability analysis has been performed in case of no tumor cells in the system. It is determined that the stability of the system in case of no tumor cells and healthy cells is related with the minimum virus dosage injected into the host. In case of no tumor cells, but healthy cells, the minimum dosage is smaller than the previous case for stability of the equilibrium point. Therefore, this study demonstrates that existence of healthy cells in the host increases the chance of eradication of tumor cells, and it leads to a decrease in virus dosage. Finally, some numerical results have been obtained for the stability analysis and numerical findings have been presented.
\end{abstract}

Keywords- Tumor Model, Stability Analysis, Oncolytic Virus, Virotherapy. 


\section{INTRODUCTION}

Cancer is a disease where some of the cells within the body divide continuously due to mutation in genes and they form tumor [1]. Some cancer cells can be eradicated by immune system [2]; but some of them may escape from immune system, and then the disease becomes harder to control [3,4]. On the other hand, the disease has still been a threat and 18.1 million new cancer cases were estimated in 2018 [5]. However, there is an increase in cancer survivors due to clinical/medical improvements [6]. As classical treatment strategies, chemotherapy [7], immunotherapy [8], radiotherapy [9] and surgery [10] can be mentioned and the choice of the appropriate treatment depends on type and stage of the disease. Need for more successful treatment strategies to eliminate tumor forces scientists to invent new therapies such as targeted chemotherapy [11] and oncolytic virotherapy [12].

Laboratory experiments to test the success of a particular treatment can be expensive and time consuming. Instead, mathematical models are easy to use, and they can be solved quickly for different values of parameters which represent different circumstances or hosts. Therefore, dynamical models have gained interest for a while and different models have been presented in the literature. For example, CTL response is modeled with a fivedimensional system [13]. On the other hand, some simple models are constructed in the work, [14] and they are validated with the real data. De Pillis et al. propose a mathematical model for tumor-immune interaction with natural killer cells and CD8+ T cells [15], whereas tumor and lymphocyte interactions are modeled by Webb et al. [16]. Effect of IL-6 to cancer survival is investigated in the work [17], while a new model including search time for immune system to attack tumor cells is included in another study by Wei [18]. A more general model is constructed by incorporating different immune cells in the study [19]. As examples to treatment strategies, we can mention the study of De Pillis et al. [20] where immunotherapy and chemotherapy are combined. On the other hand, drug resistance is investigated in case of metronomic chemotherapy [21] as another challenge for cancer treatment.

The studies mentioned above take tumor and immune cells into account. However, oncolytic virotherapy, where some engineered viruses are injected into the host to boost the immune system, has gained interest for a while [22]. From the mathematical point of view, we can mention two of the pioneer works [23, 24] where dynamics of uninfected and infected tumor cells and virus are modeled. An extended model with anti-tumor and anti-virus immune response is presented by Wodarz [25]. Furthermore, another model [26] where a fivedimensional model is constructed with susceptible/infected healthy/tumor cells together with the virus, whereas the effect of M1 and M2 macrophages are investigated by Eftimie [27]. Indeed, a seven-dimensional model is proposed including healthy cells, tumor cells, immune response and viruses in the recent work of Mahasa et al. [28]. As a different point of view, nutrient is included in the work [29] and contribution of M1 virus is investigated to eradicate tumor burden.

In this current work, we extend the model given in the study [Eq. (1.1), 29]. In the work of Wang et al. [29], a dynamical model is constructed based on the experimental findings in the study [30] to test the role of oncolytic virus M1. The model in the study [29] assumes that healthy (normal) cells $N(t)$ and tumor cells $T(t)$ increase due to interaction with nutrients $S(t)$ where concentration of nutrition and the virus $\mathrm{V}(t)$ increase by a constant source term. Moreover, interaction of tumor cells with the virus contributes to virus population. All unknown functions decay due to washout rate and the cells are subject to natural death. For reader to follow the idea easily, we mention the model in the study of Wang et al. [29]. We extend this model by including infected tumor cells $I(t)$ and logistic growth term is used for normal cells as done in the work of De Pillis and Radunskaya [31]. Afterwards, we investigate the effect of oncolytic virus and minimum virus dosage in case of logistics growth rate of normal cells and infected tumor cells in the model by presenting stability analysis of tumor free equilibrium point(s). The rest of the study is organized as follows: In Sec. II, we discuss the construction of the new model. In Sec.III, we perform the stability analysis of tumor free equilibrium point. Then, numerical results are presented in Sec.IV. The study ends with summary and conclusion.

\section{MATHEMATICAL MODEL}

In this section, we construct a new mathematical model motivated by the study [29] to investigate the impact of oncolytic virus to eradicate tumor cells in the host. The model consists of five components, namely concentration of nutrient $\mathrm{S}(t)$, concentration of healthy (normal) cells $N(t)$, concentration of uninfected and 
infected tumor cells $T(t), I(t)$, respectively. The last component is concentration of virus $V(t)$. Nutrient is supplied to the system at a rate of $f$ and tumor cells use it to replicate themselves, whereas nutrient diminishes at a rate of $d$. For normal cells, we use logistics growth [31] and they decay due to natural death and washout. Tumor cells are split into two parts as uninfected and infected tumor cells, where they use nutrient to replicate. After interaction of tumor cells with virus, some of them are transferred to the class of infected tumor cells. On the other hand, tumor cells and normal cells compete with each other. Infected tumor cells are produced as mentioned before. Concentration of virus is increased by injected medication and infected tumor cells, while it decays due to interaction with tumor cells. Indeed, concentrations of tumor cells and virus decrease due to natural death and washout. When we express these relations as a dynamical system, then we reach the mathematical model in Eq.(1)(6) where all parameters are non-negative.

$$
\begin{aligned}
& \frac{d S(t)}{d t}=f-a_{2} S(t) T(t)-a_{4} S(t) I(t)-\mu S(t), \\
& \frac{d N(t)}{d t}=r_{1} N(t)\left(1-\frac{N(t)}{K}\right)-\left(\mu+e_{1}\right) N(t), \\
& \frac{d T(t)}{d t}=r_{2} a_{2} S(t) T(t)-a_{3} T(t) V(t)-a_{5} T(t) N(t)-\left(\mu+e_{2}\right) T(t), \\
& \frac{d I(t)}{d t}=r_{3} a_{3} T(t) V(t)+r_{4} a_{4} S(t) I(t)-\left(\mu+e_{3}\right) I(t), \\
& \frac{d V(t)}{d t}=g+\alpha I(t)-a_{3} T(t) V(t)-\left(\mu+e_{4}\right) V(t), \\
& S(0)=S_{0,} N(0)=N_{0} T(0)=T_{0,} I(0)=I_{0}, V(0)=V_{0} .
\end{aligned}
$$

\section{STABILITY ANALYSIS}

We present stability analysis for the model (1)-(6) to test the contribution of M1 virus to eliminate tumor cells. Before doing this, as suggested in the study [29], we consider a reduced model for $S, N, T$ by eliminating M1 virus and infected tumor cells.

\section{A. Dynamics of $S, N$ and $T$ cells}

We consider the model consisting of nutrient $S$, healthy cells $N$ and uninfected tumor cells $T$ as

$$
\begin{aligned}
& \frac{d S(t)}{d t}=f-a_{2} S(t) T(t)-\mu S(t), \\
& \frac{d N(t)}{d t}=r_{1} N(t)\left(1-\frac{N(t)}{K}\right)-\left(\mu+e_{1}\right) N(t), \\
& \frac{d T(t)}{d t}=r_{2} a_{2} S(t) T(t)-a_{5} T(t) N(t)-\left(\mu+e_{2}\right) T(t), \\
& S(0)=S_{0} N(0)=N_{0}, T(0)=T_{0} .
\end{aligned}
$$

The idea behind finding equilibrium points is to determine all possible solutions of the equations

$$
\frac{d S(t)}{d t}=0=\frac{d N(t)}{d t}=\frac{d T(t)}{d t} .
$$

We find the equilibrium points where tumor cells or normal (healthy) cells are extinct. Firstly, we take the right hand side of the Eq. (8) into $N(t)$ paranthesis and rewrite it as $N(t)\left(r_{1}-\frac{r_{1} N(t)}{K}-\left(\mu+e_{1}\right)\right)=0$. and then the solutions are given as $\bar{N}(t)=0$ or $\bar{N}(t)=\frac{K\left(r_{1}-\mu-e_{1}\right)}{r_{1}}=\frac{K\left(\mu+e_{1}\right)}{r_{1}}\left(B_{1}-1\right)$ if $B_{1}:=\frac{r_{1}}{\mu+e_{1}}>1$. 
- If $\bar{N}(t)=0$, then Eq. (9) becomes $T(t)\left(r_{2} a_{2} S(t)-\left(\mu+e_{2}\right)\right)=0$. It leads to two solutions as $\bar{T}(t)=$ 0 or $\bar{S}(t)=\frac{\mu+e_{2}}{r_{2} a_{2}}$. Then, we obtain two equilibrium points as $E_{0}=\left(\frac{f}{\mu}, 0,0\right)$ and $E_{1}=$ $\left(\frac{\mu+e_{2}}{r_{2} a_{2}}, 0, \frac{f r_{2} a_{2}-\mu\left(\mu+e_{2}\right)}{a_{2}\left(\mu+e_{2}\right)}\right)=\left(\frac{\mu+e_{2}}{r_{2} a_{2}}, 0, \frac{\mu}{a_{2}}\left(B_{2}-1\right)\right)$ where $B_{2}:=\frac{f r_{2} a_{2}}{\mu\left(\mu+e_{2}\right)}$. Here,for $E_{1}$ to be feasible, $B_{2}>$ 1 must hold.

- If $\bar{T}(t)=0$, then Eq. (7) gives $\bar{S}(t)=\frac{f}{\mu}$. Then, we obtain an equilibrium point as

$E_{2}=\left(\frac{f}{\mu}, \frac{K\left(r_{1}-\mu-e_{1}\right)}{r_{1}}, 0\right)=\left(\frac{f}{\mu}, \frac{K\left(\mu+e_{1}\right)}{r_{1}}\left(B_{1}-1\right), 0\right)$. Similarly, for a feasible equilibrium point, $B_{1}>1$ must be satisfied.

Here, we note that there are other equilibrium points where tumor cells and/or normal cells coexist; but, we restrict ourselves to these cases to observe the contribution of oncolytic virus to eradication of tumor cells. Since the equilibrium point $E_{0}$ corresponds to the case where there is only nutrient within the host, we don't investigate this equilibrium point. Instead, we proceed with the stability analysis of $E_{1}$ and $E_{2}$. matrix

Equilibrium point $E_{1}$ : We obtain the Jacobian of the model (7)-(9) and evaluate it at $E_{1}$ to obtain the

$$
J\left(E_{1}\right)=\left(\begin{array}{ccc}
-\mu B_{2} & 0 & \frac{-\left(\mu+e_{2}\right)}{r_{2}} \\
0 & \left(\mu+e_{1}\right)\left(B_{1}-1\right) & 0 \\
r_{2} \mu\left(B_{2}-1\right) & \frac{-a_{5} \mu}{a_{2}}\left(B_{2}-1\right) & 0
\end{array}\right)
$$

We immediately see that one of the eigenvalues of the matrix (3) is $\lambda_{1}=\left(\mu+e_{1}\right)\left(B_{1}-1\right)$ and it is negative if $B_{1}<1$. To find the other eigenvalues, we obtain the characteristics equation of the matrix in (12) as

$$
p(\lambda)=\left(\lambda-\left(\left(\mu+e_{1}\right)\left(B_{1}-1\right)\right)\right)\left(\lambda^{2}+\mu B_{2} \lambda+\mu\left(\mu+e_{2}\right)\left(B_{2}-1\right)\right) .
$$

For other eigenvalues to be negative, the term $\mu\left(\mu+e_{2}\right)\left(B_{2}-1\right)$ must be positive, since $\mu B_{2}>0$. Then, we get the condition $B_{2}>1$ for stability. We conclude that $E_{1}$ is stable if both $B_{1}<1$ and $B_{2}>1$ hold. We summarize the result as a theorem below.

Theorem 1: The equilibrium point $E_{1}$ exists if $B_{2}>1$. Indeed, it is locally asymptotically stable if $B_{1}<1$ and $B_{2}>1$ hold.

Equilibrium point $E_{2}$ : We consider the Jacobian of the model (7)-(9) and evaluate it at $E_{2}$ to obtain the matrix

$$
J\left(E_{2}\right)=\left(\begin{array}{ccc}
-\mu & 0 & \frac{-a_{2} f}{\mu} \\
0 & -\left(\mu+e_{1}\right)\left(B_{1}-1\right) & 0 \\
0 & 0 & \left(\mu+e_{2}\right)\left(B_{2}-1\right)-a_{5} K \frac{\mu+e_{1}}{r_{1}}\left(B_{1}-1\right)
\end{array}\right)
$$

Eigenvalues of the matrix in Eq. (13) are given by the entries on the diagonal as $\lambda_{1}=-\mu, \lambda_{2}=-(\mu+$ $\left.e_{1}\right)\left(B_{1}-1\right)$ and $\lambda_{3}=\left(\mu+e_{2}\right)\left(B_{2}-1\right)-a_{5} K \frac{\mu+e_{1}}{r_{1}}\left(B_{1}-1\right)$. For $\lambda_{2}$ to be negative, we find that $B_{1}>1$, which is the condition to reach a feasible equilibrium point. For $\lambda_{3}<0$, we find that $B_{2}<\frac{K a_{5}\left(\mu+e_{1}\right)}{r_{1}\left(\mu+e_{2}\right)}\left(B_{1}-1\right)+1$ must hold. Now, we summarize the result below.

Theorem 2: The equilibrium point $E_{2}$ exists if $B_{1}>1$. Indeed, it is locally asymptotically stable if $B_{1}>$ 1and $B_{2}<\frac{K a_{5}\left(\mu+e_{1}\right)}{r_{1}\left(\mu+e_{2}\right)}\left(B_{1}-1\right)+1$ hold. 
The model (7)-(9) is not symmetric in $\mathrm{T}$ and $\mathrm{N}$ due to the competition between tumor and normal cells, namely the term $a_{5} T N$. It leads to unsymmetric conditions for stability of the equilibrium points $E_{1}$ and $E_{2}$. Indeed, the extra term in the upper bound of $B_{2}$ in Thm. 2 is on account of this unsymmetric model.

\section{A. Dynamics of the new model}

We proceed with the new model in Eq. (1)-(5). We restrict ourselves to the case where tumor cells are extinct and we find tumor-free equilibrium point. Indeed, we take $T=I=0$ in Eq. (1) and proceed. From Eq. (2), we get two solutions as $\bar{N}(t)=0$ or $\bar{N}(t)=\frac{K\left(r_{1}-\mu-e_{1}\right)}{r_{1}}=\frac{K\left(\mu+e_{1}\right)}{r_{1}}\left(B_{1}-1\right)$ if $B_{1}:=\frac{r_{1}}{\mu+e_{1}}>1$. Indeed,

- $\quad$ From Eq. (1), we have $\bar{S}=\frac{f}{\mu}$.

- $\quad$ From Eq. (5), we find $\bar{V}=\frac{g}{\mu+e_{4}}$.

- If $\bar{N}(t)=0$, then we find the equilibrium point as $E_{3}=\left(\frac{f}{\mu}, 0,0,0, \frac{g}{\mu+e_{4}}\right)$.

- If $\bar{N}(t)=\frac{K\left(\mu+e_{1}\right)}{r_{1}}\left(B_{1}-1\right)$, then we reach $E_{4}=\left(\frac{f}{\mu}, \frac{K\left(\mu+e_{1}\right)}{r_{1}}\left(B_{1}-1\right), 0,0, \frac{g}{\mu+e_{4}}\right)$.

We proceed with the stability of $E_{3}$ and $E_{4}$

Equilibrium point $E_{3}$ : The Jacobian of the model (1)-(5) is evaluated at $E_{3}$ to obtain the matrix

$$
J\left(E_{3}\right)=\left(\begin{array}{ccccc}
-\mu & 0 & \frac{-a_{2} f}{\mu} & \frac{-a_{4} f}{\mu} & 0 \\
0 & \left(\mu+e_{1}\right)\left(B_{1}-1\right) & 0 & 0 & 0 \\
0 & 0 & \left(\mu+e_{2}\right)\left(B_{2}-1\right)-\frac{g a_{3}}{\mu+e_{4}} & 0 & 0 \\
0 & 0 & \frac{r_{3} a_{3} g}{\mu+e_{4}} & \left(\mu+e_{3}\right)\left(B_{3}-1\right) & 0 \\
0 & 0 & \frac{-a_{3} g}{\mu+e_{4}} & \alpha & -\left(\mu+e_{4}\right)
\end{array}\right)
$$

The eigenvalues of this block diagonal matrix in Eq. (14) are given by $\lambda_{1}=-\mu, \lambda_{2}=\left(\mu+e_{1}\right)\left(B_{1}-1\right)$, $\lambda_{3}=\left(\mu+e_{2}\right)\left(B_{2}-1\right)-\frac{g a_{3}}{\mu+e_{4}}, \lambda_{4}=\left(\mu+e_{3}\right)\left(B_{3}-1\right), \lambda_{5}=-\left(\mu+e_{4}\right)$ where $B_{3}:=\frac{r_{4} a_{4} f}{\mu\left(\mu+e_{3}\right)}$. For stability, the second eigenvalue leads to the condition $B_{1}<1$, whereas the third eigenvalue gives the condition that $\lambda_{3}<$ 0which leads to $B_{2}<\frac{g a_{3}}{\left(\mu+e_{2}\right)\left(\mu+e_{4}\right)}+1$. Rewriting this condition, we find a threshold value for the virus source injected into the host, namely $g$, as $g_{0}=\frac{\left(\mu+e_{2}\right)\left(\mu+e_{4}\right)}{a_{3}}\left(B_{2}-1\right)<g$. It must be noted that the recruitment rate of the virus cannot be negative, so $g_{0} \geq 0$ must hold. This leads to another condition $B_{2} \geq 1$. If the term $g$ is smaller than $g_{0}$, then $E_{3}$ is unstable. This result is written as follows:

Theorem 3: The equilibrium point $E_{3}$ is locally asymptotically stable if $g_{0}=\frac{\left(\mu+e_{2}\right)\left(\mu+e_{4}\right)}{a_{3}}\left(B_{2}-1\right)<$ gholds together with $B_{1}<1, B_{3}<1$ and $B_{2} \geq 1$.

Equilibrium point $E_{4}$ : The Jacobian of the model (1)-(5) is evaluated at $E_{4}$ to obtain the matrix

$$
J\left(E_{4}\right)=\left(\begin{array}{ccccc}
-\mu & 0 & \frac{-a_{2} f}{\mu} & \frac{-a_{4} f}{\mu} & 0 \\
0 & -\left(\mu+e_{1}\right)\left(B_{1}-1\right) & 0 & 0 & 0 \\
0 & 0 & \Omega & 0 & 0 \\
0 & 0 & \frac{r_{3} a_{3} g}{\mu+e_{4}} & \left(\mu+e_{3}\right)\left(B_{3}-1\right) & 0 \\
0 & 0 & \frac{-a_{3} g}{\mu+e_{4}} & \alpha & -\left(\mu+e_{4}\right)
\end{array}\right) \text {, }
$$


where $\Omega=\left(\mu+e_{2}\right)\left(B_{2}-1\right)-\frac{g a_{3}}{\mu+e_{4}}-\frac{K a_{5}\left(\mu+e_{1}\right)}{r_{1}}\left(B_{1}-1\right)$. Similarly, the entries on the main diagonal are the eigenvalues of this block diagonal matrix and they are $\lambda_{1}=-\mu, \lambda_{2}=-\left(\mu+e_{1}\right)\left(B_{1}-1\right), \lambda_{3}=\Omega, \lambda_{4}=(\mu+$ $\left.e_{3}\right)\left(B_{3}-1\right)$ and $\lambda_{5}=-\left(\mu+e_{4}\right)$. For stability, we obtain that $B_{1}>1, \Omega<0$ and $B_{3}<1$ must hold. The second condition gives us the following relation: $B_{2}<\frac{g a_{3}}{\left(\mu+e_{2}\right)\left(\mu+e_{4}\right)}+\frac{K a_{5}\left(\mu+e_{1}\right)}{r_{1}\left(\mu+e_{2}\right)}\left(B_{1}-1\right)+1$. Indeed, we find a condition on the minimum virus source as $0 \leq g_{1}=: \frac{\left(\mu+e_{2}\right)\left(\mu+e_{4}\right)}{a_{3}}\left(B_{2}-1\right)-\frac{K a_{5}\left(\mu+e_{1}\right)\left(\mu+e_{4}\right)}{r_{1} a_{3}}\left(B_{1}-1\right)<g$. Unless the source term $g$ is greater than $g_{1}, E_{4}$ is unstable. Now, we present the last theorem of this study below.

Theorem 4: The equilibrium point $E_{4}$ exists if $B_{1}>1$. Moreover, it is locally asymptotically stable if

$$
0 \leq g_{1}=: \frac{\left(\mu+e_{2}\right)\left(\mu+e_{4}\right)}{a_{3}}\left(B_{2}-1\right)-\frac{K a_{5}\left(\mu+e_{1}\right)\left(\mu+e_{4}\right)}{r_{1} a_{3}}\left(B_{1}-1\right)<\text { gand } B_{3}<1 \text { hold. }
$$

When we compare Thm.3 and Thm.4, we observe that the lower bound on the dosage $g$ is lower for $E_{4}$ than the bound for $E_{3}$. In other words, the condition on the dosage, namely $g_{1}$, to make equilibrium point $E_{4}$ (where $N \neq 0$ ) stable is less restrictive than the condition, namely $g_{0}$, associated with the case where $N=0$. It is because of the competition between tumor cells and healthy cells, that is, the term $a_{5} T N$. Since this term contributes to eradication of tumor cells, a smaller dose of virotherapeutic drug is enough for $E_{4}$ to be stable.

\section{NUMERICAL RESULTS}

Some numerical examples will be presented to discuss the theorems in the previous sections. Numerical results are obtained with the use of ode 45 function of MATLAB. The system is solved from $t=0$ to $t=1000$ to see the overall trend of the solution.

\section{A. Examples for $\mathrm{S}$-N-T model}

We take the values of the parameters as $f=0.02, a_{2}=0.5, \mu=0.02, e_{1}=0.01, e_{2}=0.008[\mathrm{Sec} .4,29]$ and we choose the others as $K=1, a_{5}=0.8$. The values of $r_{1}$ and $r_{2}$ will be specified later.

We start with $E_{1}$ and we take $r_{1}=0.02, r_{2}=0.8$. The initial conditions are fixed as $S_{0}=0.15, N_{0}=$ $0.05, T_{0}=0.8$. With these choice of the parameters, $B_{1}=0.6667<1$ and $B_{2}=14.2857>1$ as required by $\mathrm{Thm} .1$ for stability and we observe that the solution converges to the equilibrium point $E_{1}=(0.07,0,0.5314)$ as shown in Fig. 1.

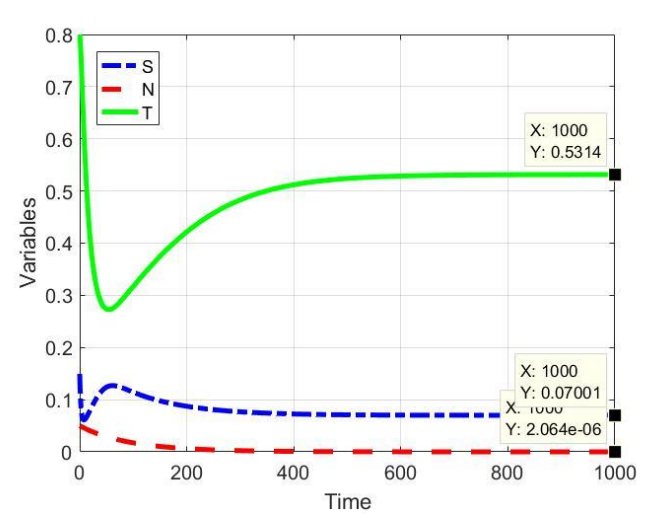

Figure 1. Numerical solution associated with $E_{1}$. 
We proceed with $E_{2}$ by taking $r_{1}=0.05, r_{2}=0.2$. The initial conditions are chosen as $S_{0}=0.15, N_{0}=$ $0.8, T_{0}=0.05$. We calculate $B_{1}=1.6667>1$ and $B_{2}=3.5714<\frac{K a_{5}\left(\mu+e_{1}\right)}{r_{1}\left(\mu+e_{2}\right)}\left(B_{1}-1\right)+1=12.4286$, which agrees with Thm.2. Thus, the solution converges to the equilibrium point $E_{2}=(1,0.4,0)$, as shown in Fig.2.

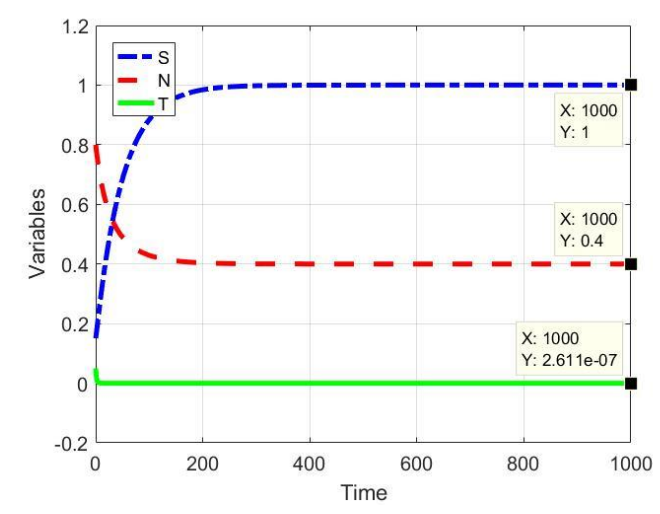

Figure 2. Numerical solution associated with $E_{2}$.

\section{B. Examples For The New Model}

We test the contribution of M1 virus to tumor eradication. The new parameter values are set as $a_{3}=$ $0.1, r_{3}=0.5 \quad\left[\right.$ Sec.4, 29] and $a_{2}=0.05, a_{4}=0.2, r_{1}=0.01, r_{2}=0.8, \alpha=0.1, e_{4}=0.01, a_{5}=0.9, e_{3}=$ $0.1, r_{4}=0.2$. Two different values of $g$ will be used to test numerical stability.

As the first case, we fix $g=0.01$ and the initial conditions are chosen as $S_{0}=0.7, N_{0}=0.05, T_{0}=$ $0.03, I_{0}=0.02, V_{0}=0.2$. With these choices of the parameters, $g_{0}=0.084>g=0.01$, which contradicts with Thm.3. The solution does not converge to the equilibrium point $E_{3}$, as shown in Fig.3.

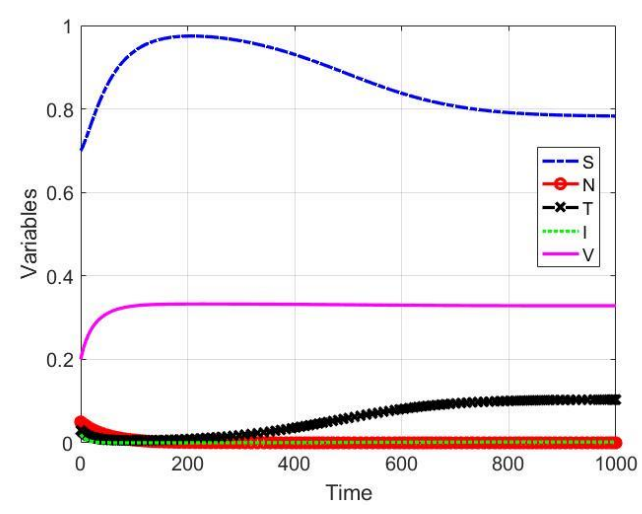

Figure 3. Numerical solution associated with $E_{3}$.

Now, as the second case, we set $g=0.1>g_{0}=0.084$. Then, we observe that $B_{1}=B_{3}=0.3333<1$ and $B_{2}=1.4286>1$. By Thm.3, the equilibrium point $E_{3}=(1,0,0,0,0.3333)$ is stable as can be seen in Fig.4. 


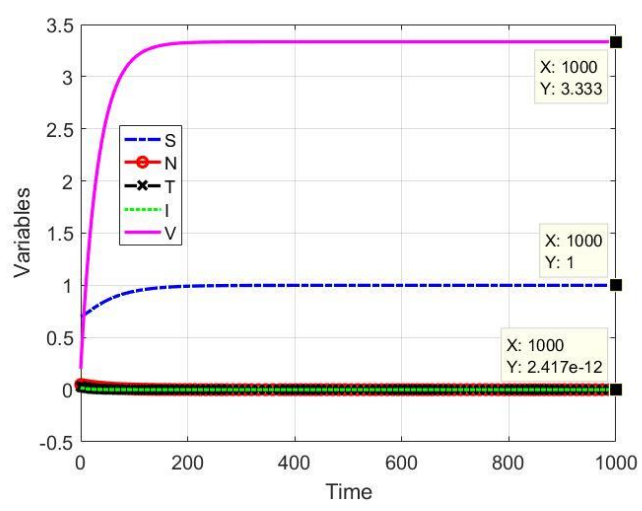

Figure 4. Numerical solution associated with $E_{3}$

We proceed with $E_{4}$ by fixing $a_{2}=0.5, r_{1}=0.04, a_{3}=0.1, g=0.01, S_{0}=0.6, N_{0}=0.25, T_{0}=$ $0.03, I_{0}=0.02, V_{0}=0.1$. Then, we compute $g_{1}=0.0441>g=0.01$. Therefore, the solution does not converge to the equilibrium point $E_{4}$ as shown in Fig.5.

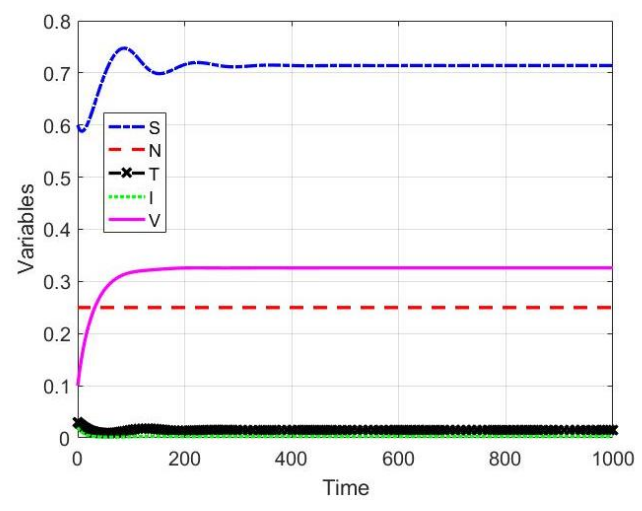

Figure 5. Numerical solution associated with $E_{4}$

We change the source term as $g=0.05>g_{1}=0.0441$ and the conditions in Thm. 4 , namely $B_{1}=$ $1.3333>1, B_{3}=0.3333<1$ are satisfied. Thus, with these values of the parameters, $E_{4}=$ $(1,0.25,0,0,1.667)$ is stable and we plot the solution in Fig.6.

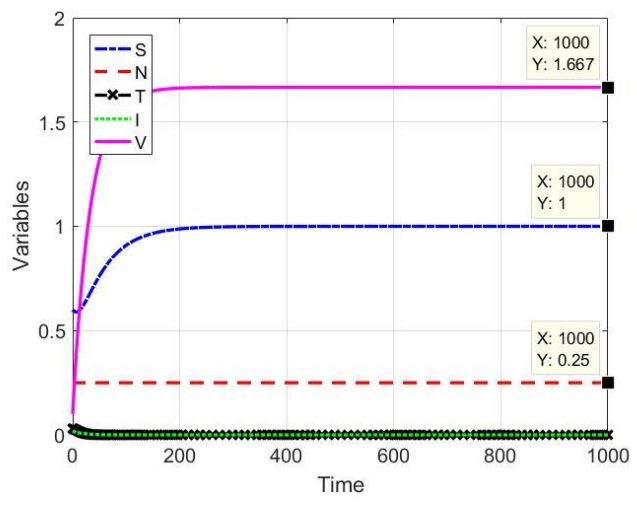

Figure 6. Numerical solution associated with $E_{4}$ 


\section{SUMMARY AND CONCLUSION}

We extend a mathematical model given in the study [29] to investigate the contribution of oncolytic virotherapy. Tumor cells are split into two classes as uninfected and infected tumor cells which is not the case in the study [29]. On the other hand, logistic growth is used for healthy cells. Competition between tumor cells and normal cells are included so that we can test the impact of the competition to drug use to eradicate tumor burden. Afterwards, tumor free equilibrium points are found and their stability is discussed. We determine that the stability of the system in case of no tumor cells and healthy cells is related with the minimum virus dosage injected into the host. In case of no tumor cells, but healthy cells, the minimum dosage is smaller than the previous case for stability of the equilibrium point. Therefore, we find out that existence of healthy cells in the host increases the chance of eradication of tumor cells with a smaller virus recruitment rate. Finally, we present some numerical results to exemplify our theoretical findings.

\section{ACKNOWLEDGMENT}

The author is grateful to the anonymous referees for their valuable comments and helpful suggestions, which helped to improve the presentation of this work.

\section{REFERENCES}

[1] National Cancer Institute. July, 2019. What is cancer? https://www.cancer.gov/aboutcancer/understanding/what-is-cancer.

[2] Schreiber, R. D., Old, L. J., \& Smyth, M. J. (2011). Cancer immunoediting: integrating immunity’s roles in cancer suppression and promotion. Science, 331(6024), 1565-1570.

[3] Finn, O. J. (2012). Immuno-oncology: understanding the function and dysfunction of the immune system in cancer. Annals of Oncology, 23(suppl_8), viii6-viii9.

[4] Dunn, G. P., Old, L. J., \& Schreiber, R. D. (2004). The three Es of cancer immunoediting. Annual Reviews of Immunology, 22, 329-360.

[5] Bray, F., Ferlay, J., Soerjomataram, I., Siegel, R. L., Torre, L. A., \& Jemal, A. (2018). Global cancer statistics 2018: GLOBOCAN estimates of incidence and mortality worldwide for 36 cancers in 185 countries. $C A: A$ Cancer Journal for Clinicians, 68(6), 394-424.

[6] Miller, K. D., Siegel, R. L., Lin, C. C., Mariotto, A. B., Kramer, J. L., Rowland, J. H., Stein, K. D., Alteri, R. \& Jemal, A. D.V.M. (2016). Cancer treatment and survivorship statistics, 2016. CA: A Cancer Journal for Clinicians, 66(4), 271-289.

[7] Mamat, M., Subiyanto, K. A., \& Kartono, A. (2013). Mathematical model of cancer treatments using immunotherapy, chemotherapy and biochemotherapy. Applied Mathematical Sciences, 7(5), 247-261.

[8] Melief, C. J. (2008). Cancer immunotherapy by dendritic cells. Immunity, 9(3), 372-383.

[9] Senkus-Konefka, E., \& Jassem, J. (2006). Complications of breast-cancer radiotherapy. Clinical Oncology, $18(3), 229-235$.

[10] Brennan, M. F. (2005). Current status of surgery for gastric cancer: A review. Gastric Cancer, 8(2), 64-70.

[11] Zhang, J., Yang, P. L., \& Gray, N. S. (2009). Targeting cancer with small molecule kinase inhibitors. Nature Reviews Cancer, 9(1), 28.

[12] Russell, S. J., Peng, K. W., \& Bell, J. C. (2012). Oncolytic virotherapy. Nature Biotechnology, $30(7), 658$. 
[13] Kuznetsov, V. A., Makalkin, I. A., Taylor, M. A., \& Perelson, A. S. (1994). Nonlinear dynamics of immunogenic tumors: parameter estimation and global bifurcation analysis. Bulletin of Mathematical Biology, 56(2), 295-321.

[14] Enderling, H., \& Chaplain, M. A. J. (2014). Mathematical modeling of tumor growth and treatment. Current pharmaceutical design, 20(30), 4934-4940.

[15] De Pillis, L. G., Radunskaya, A. E., \& Wiseman, C. L. (2005). A validated mathematical model of cellmediated immune response to tumor growth. Cancer Research, 65(17), 7950-7958.

[16] Webb, S. D., Sherratt, J. A., \& Fish, R. G. (2002). Cells behaving badly: a theoretical model for the Fas/FasL system in tumour immunology. Mathematical Biosciences, 179(2), 113-129.

[17] Nazari, F., Pearson, A. T., Nör, J. E., \& Jackson, T. L. (2018). A mathematical model for IL-6-mediated, stem cell driven tumor growth and targeted treatment. PLoS Computational Biology, 14(1), e1005920.

[18] Wei, H. C. (2018). A mathematical model of tumour growth with Beddington-DeAngelis functional response: a case of cancer without disease. Journal of Biological Dynamics, 12(1), 194-210.

[19] Robertson-Tessi, M., El-Kareh, A., \& Goriely, A. (2012). A mathematical model of tumor-immune interactions. Journal of Theoretical Biology, 294, 56-73.

[20] De Pillis, L. G., Gu, W., \& Radunskaya, A. E. (2006). Mixed immunotherapy and chemotherapy of tumors: modeling, applications and biological interpretations. Journal of Theoretical Biology, 238(4), 841-862.

[21] Ledzewicz, U., Wang, S., Schättler, H., André, N., Heng, M. A., \& Pasquier, E. (2017). On drug resistance and metronomic chemotherapy: A mathematical modeling and optimal control approach. Mathematical Biosciences \& Engineering, 14(1), 217-235.

[22] Lawler, S. E., Speranza, M. C., Cho, C. F., \& Chiocca, E. A. (2017). Oncolytic viruses in cancer treatment: A review. JAMA Oncology, 3(6), 841-849.

[23] Dingli, D., Cascino, M. D., Josić, K., Russell, S. J., \& Bajzer, Ž. (2006). Mathematical modeling of cancer radiovirotherapy. Mathematical Biosciences, 199(1), 55-78.

[24] Bajzer, Ž., Carr, T., Josić, K., Russell, S. J., \& Dingli, D. (2008). Modeling of cancer virotherapy with recombinant measles viruses. Journal of Theoretical Biology, 252(1), 109-122.

[25] Wodarz, D. (2004). Computational approaches to study oncolytic virus therapy: insights and challenges. Gene Therapy and Molecular Biology, 8, 137-146.

[26] Okamoto, K. W., Amarasekare, P., \& Petty, I. T. (2014). Modeling oncolytic virotherapy: Is complete tumortropism too much of a good thing?. Journal of Theoretical Biology, 358, 166-178.

[27] Eftimie, R., \& Eftimie, G. (2018). Tumour-associated macrophages and oncolytic virotherapies: a mathematical investigation into a complex dynamics. Letters in Biomathematics, 5(sup1), S6-S35.

[28] Mahasa, K. J., Eladdadi, A., De Pillis, L., \& Ouifki, R. (2017). Oncolytic potency and reduced virus tumorspecificity in oncolytic virotherapy. A mathematical modelling approach. PloS One, 12(9), e0184347.

[29] Wang, Z., Guo, Z., \& Peng, H. (2016). A mathematical model verifying potent oncolytic efficacy of M1 virus. Mathematical Biosciences, 276, 19-27.

[30] Lin, Y., Zhang, H., Liang, J., Li, K., Zhu, W., Fu, L., et al (2014). Identification and characterization of alphavirus M1 as a selective oncolytic virus targeting ZAP-defective human cancers. Proceedings of the National Academy of Sciences, 111(42), E4504-E4512. 


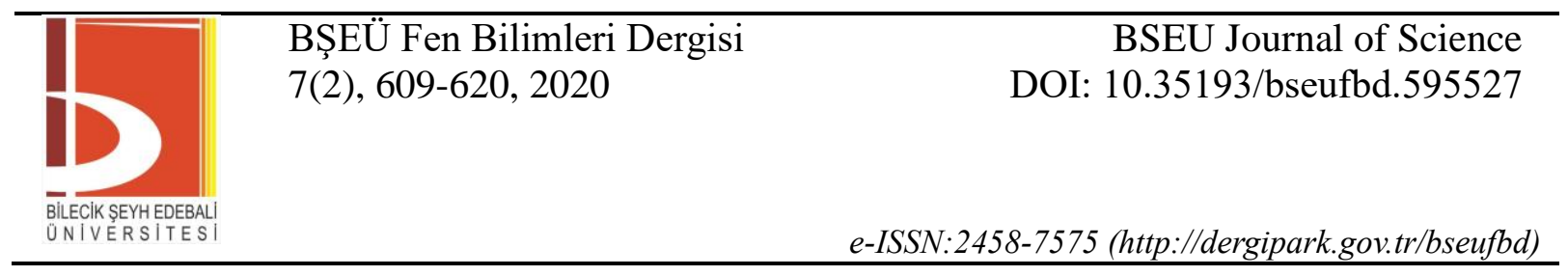

[31] De Pillis, L. G., \& Radunskaya, A. (2003). The dynamics of an optimally controlled tumor model: A case study. Mathematical and Computer Modelling, 37(11), 1221-1244. 